\title{
LANDUSE AND LAND COVER CHANGE IN THE LUNAN STONE FOREST, CHINA
}

\author{
UPORABA POVRŠJA IN SPREMEMBE RASTLINSKEGA \\ POKROVA V LUNANSKEM KAMNITEM GOZDU, KITAJSKA
}

CHUANRONG ZHANG \& MICHAEL DAY \& WEIDONG LI

${ }^{1}$ Department of Geography, University of Wisconsin-Milwaukee, Milwaukee, Wisconsin 53201, USA.

E-mail: czhang@uwm.edu mickday@uwm.edu weidong6616@yahoo.com

Prejeto / received: 4. 7. 2003 


\section{Abstract \\ UDC: 551.44:504.03(510) \\ Chuanrong Zhang \& Michael Day \& Weidong Li: Landuse and Land Cover Change in the Lunan Stone Forest, China}

The Lunan Stone Forest is the World's premier pinnacle karst landscape, with attendant scientific and cultural importance. Ecologically fragile, it is also a major tourist attraction, currently receiving over 1.5 million visitors each year. Conservation efforts have been undermined by conflicting economic priorities, and landscape degradation threatens the very foundation of the national park. Assessment of the current land cover in the $35 \mathrm{~km}^{2}$ core of the Stone Forest and an analysis of land cover change since 1974 in the $7 \mathrm{~km}^{2}$ Major Stone Forest reveal the extent of recent landscape change. Exposed pinnacle karst covers $52 \%$ of the $35 \mathrm{~km}^{2}$ study area, and about half of this is vegetated. Land use is dominated by agriculture, particularly in the valleys, but much of the shilin is devegetated and about six percent of the area is now built-up. Within the $7 \mathrm{~km}^{2}$ Major Stone Forest the built-up area increased from $0.15 \mathrm{ha}$ in 1974 to $38.68 \mathrm{ha}$ by 2001, and during that same period road length increased by $95 \%$, accompanied by a $3 \%$ decrease in surface water area. Between 1980 and 2001, annual visitor numbers increased from 139,000 to 1,500,000 - a ten-fold increase. The need to reconcile economic development and landscape conservation involves both short-term versus long-term benefit and also the conservation of natural and cultural heritage.

Key words: karst conservation, human impact, shilin, Lunan, China.

\section{Izvleček}

UDK: 551.44:504.03(510)

\section{Chuanrong Zhang \& Michael Day \& Weidong Li: Uporaba površja in spremembe rastlinskega pokrova v lunanskem Kamnitem gozdu, Kitajska}

Lunanski Kamniti gozd (Šilin) je najboljši primer takega tipa kraške pokrajine na svetu, ustreznega znanstvenega in kulturnega pomena. Kljub ekološki krhkosti je to ena največjih turističnih privlačnosti, ki jo letno obišče preko 1.5 milijona turistov. Njegovo ohranjanje spodkopavajo nasprotujoče si gospodarske prednosti in degradacija površja ogro•a sam obstoj narodnega parka. Ugotavljanje sedanjega rastlinskega pokrova v $35 \mathrm{~km}^{2}$ velikem osrednjem delu Kamnitega gozda in analiza sprememb tega pokrova od leta 1974 dalje v 7 km² obsegajočem Malem Kamnitem gozdu ka•ejo na obseg sprememb v pokrajini. Goli kraški stebri obsegajo $52 \%$ preučevanega ozemlja v obsegu $35 \mathrm{~km}^{2}$ in okoli polovica ga je poraslega. V izrabi površja prevladuje poljedelstvo, predvsem v dolinah, toda velik del šilina je ogolelega, okoli 6 \% površine pa je pozidane. Na območju $7 \mathrm{~km}^{2}$ Velikega Kamnitega gozda se je pozidana površina povečala z 0.5 ha leta 1974 na 38.68 ha leta 2001 . V istem času se je dol•ina cest povečala za $95 \%$, medtem ko so se vodne površine zmanjšale za $3 \%$. Med 1980 in 2001 se je letni obisk povečal s 139000 na 1500000 - desetkratni porast. Potreba po uskladitvi ekonomskega razvoja in ohranjanja pokrajine vsebuje primerjavo kratkoročnega $\mathrm{z}$ daljnoročnim dobičkom in tudi z ohranjanjem naravne in kulturne dediščine.

Ključne besede: ohranjanje krasa, vpliv človeka, šilin, Lunan, Kitajska. 


\section{INTRODUCTION}

\section{The Stone Forest Landscape}

The Lunan Stone Forest, or "Shilin" of Yunnan Province (Fig. 1) is one China's most unique landscapes, with a national and international reputation. With a total area of $350 \mathrm{~km}^{2}$ it is China's premier pinnacle karst landscape and the most extensive such landscape in the world (Song, 1986). Not only is it a very significant karst landscape, but also it is a landscape of cultural and ecological importance, as well as a major tourist attraction, which currently attracts over 1.5 million visitors each year.

From the perspective of karst science, the Lunan Stone Forest is unrivalled for two principal reasons. First, it preserves and displays much greater evolutionary complexity than other pinnacle karst landscapes and, second, it contains a wider array of karren morphologies than anywhere else (Song, 1997). Other international pinnacle karst landscapes, such as the pinnacles of Gunong Mulu, the assegai karst of Palawan, the aręte and pinnacle karst of Mount Kaijende, New Guinea, the tsingy of Madagascar and the karst of Chillagoe in North Queensland, do not have the same complex geological history, nor the variety of pinnacle shapes - needles, fins, flutes, ruiniform blocks, emergent stone teeth - representing different stages of evolution (Waltham, 1984; Geng et al, 1987).

The Stone Forest landscape has a complex geomorphologic character, with steep slopes, thin soils, a shallow epikarst aquifer and restricted vegetation cover, and it is inherently very fragile, with considerable

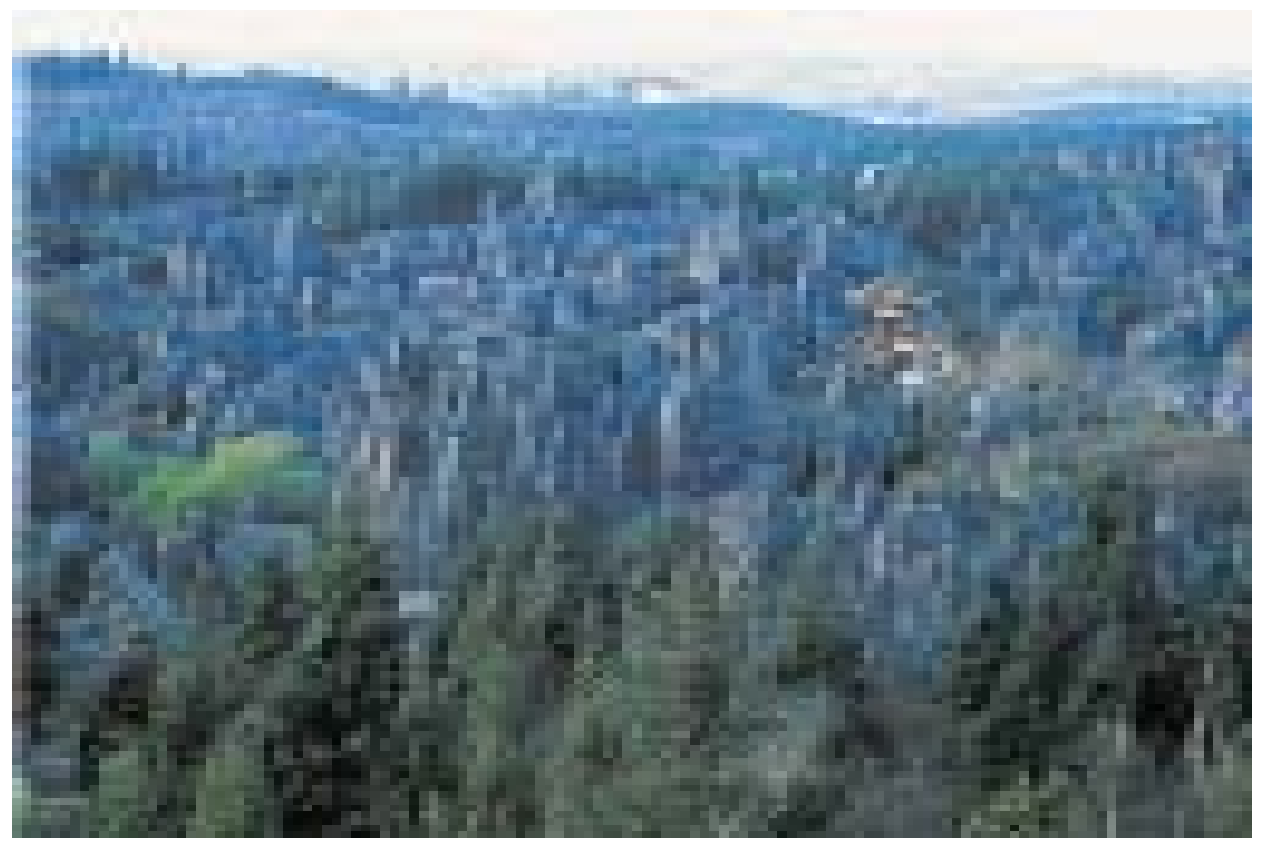

Fig. 1: The Lunan Stone Forest landscape. 
hydrological and ecosystem sensitivity (Yuan et al. 1991; Huntoon, 1992, 1993). Human population density is high $\left(1205\right.$ persons $\left./ \mathrm{km}^{2}\right)$ and there is limited farmland, leading to forest denudation and soil erosion. Rapid urban growth and increasing tourism also place serious pressure on local resources, including water supplies (Day, 1997; Kranjc and Liu 2001). Adoption by the Chinese government of economic reform policies has lead to the accelerated construction of factories and infrastructure, increasing demand for construction materials and producing air and water pollution. In response to the increasing human pressure, conservation measures have been enacted to protect the karst environment, particularly the flora, wildlife, soils, water and cultural resources, all of which have scientific, aesthetic and economic significance (Day, 1997).

The "Shilin", or Stone Forest is a karst landscape dominated by "megakarren" - particularly large forms of what are more usually smaller features that form by dissolution of exposed carbonate rock surfaces. Shilin is a "forest" of intensively corroded limestone pinnacles commonly exceeding ten meters high. Yuan (1988) defined it as "a complex landscape consisting of dense rock spires having a variety of shapes separated by numerous dissolution-widened fractures." The surfaces of the spires and the walls of the intervening pits are often vertically fluted, and they themselves contain an array of smaller karren features. The spires commonly attain $20 \mathrm{~m}$ in height, with the largest reaching 50m. The Lunan Shilin is the best-known stone forest landscape in Yunnan, although there are others in that province and also in Guizhou, Hubei, Hunan and Sichuan (Kranjc and Liu 2001).

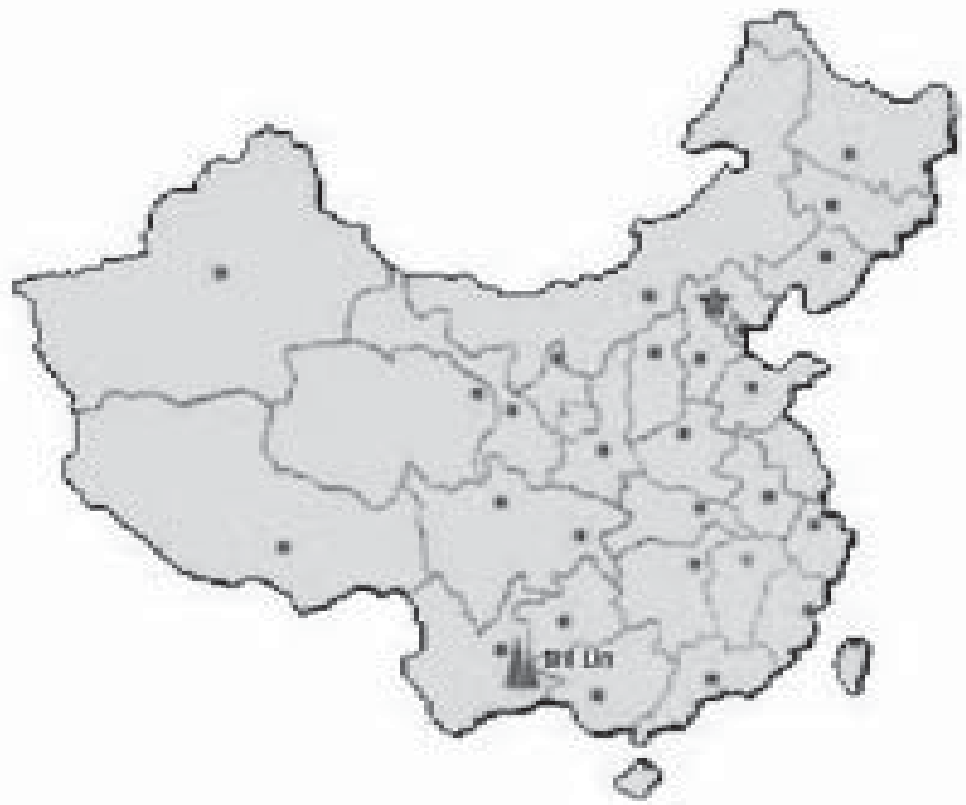

Fig. 2: Location of the Lunan Stone Forest (after Huang \& Liu, 1998). 
The Lunan Stone Forest is located about $90 \mathrm{~km}$ southeast of Kunming, the provincial capital, in the plateau karstic lake area (Lin, 1997) of eastern Yunnan at about 243'N and 103²0'E (Fig. 2). At an elevation of $1750 \mathrm{~m}$ above sea level, it experiences a subtropical monsoon climate with a mean annual temperature of $16.3^{\circ} \mathrm{C}$ and $963 \mathrm{~mm}$ of precipitation per year (Zhang, 1984). The climate is generally equable, and is often likened to year-round spring (Zhang et al, 1997). The soil is relatively poor, and stony land is common. The vegetation is composed dominantly of broad-leaved evergreen and deciduous forest (Zhang et al, 1997 ).

\section{CURRENT CONSERVATION ISSUES IN THE STONE FOREST}

The Lunan Stone Forest has been studied, exploited and, to some extent, protected since the visit of the provincial governor in 1931 (Kranjc and Liu 2001) with conservation measures being implemented incrementally as scientific studies have underlined its significance. The Chinese government has acknowledged the scientific value of Stone Forest landscape, and has recognized that its conservation will be beneficial to the local economy and culture. The Shilin was made a national park in 1982, with a "Protection Zone" extending over $350 \mathrm{~km}^{2}$. As a means of implementing protective measures in the Stone Forest, the national government in 1984 established three zones that were to be accorded different levels of protection. The Administrative Bureau of Shilin National Park was set up in 1988 and, under the auspices of the National Ministry of Construction, the government began to prepare for an application to inscribe the Lunan Shilin on the UNESCO World Natural Heritage list. An International Symposium to further this goal occurred in 1995 (Song et al 1997).

Although some measures have been taken to protect the Shilin landscape, several fundamental problems still exist, among which one is paramount. The problem is that the local government accords greater priority to economic development than to landscape conservation and protection, despite the long-term economic significance of the latter. Natural resources, including the fabric of the Stone Forest itself, are exploited, in part to encourage tourism, without regard for the degradation that will ultimately destroy the attraction of the landscape.

\section{RESEARCH OBJECTIVES AND METHODOLOGY}

The objective of this research is to quantify existing land covers and to determine how the core Stone Forest landscape has changed over recent decades. This may help the local government and residents to understand the scope of resource exploitation, recognize that protection is necessary, and identify what is necessary to effectively protect the landscape. The methodology combines GIS and remote sensing techniques to quantify current land use and land cover status in the Stone Forest and to assess landscape change over the past 30 years.

Geographical Information Systems (GIS) facilitate the capture, storage, checking, manipulation, analysis and display of data which are spatially referenced to the earth (DoE, 1987). GIS accommodates collection, manipulation and analysis of information from diverse sources, and the spatial analysis function highlights the relationships between that data and salient landscape features. In the context of conservation and protected areas, GIS can provide accessible public information for rapid identification of boundaries and, in harness with satellite-based remote sensing, can readily convey quantitative data about temporal and spatial landscape change. Remote observation 
combined with ground-based social data has the potential to improve understanding of the determinants of various land-use changes, and GIS and remote sensing represent valuable tools for the monitoring of environmental changes induced by human activity (Gao and Skillcorn, 1995; Miguel-Ayanz and Biging, 1997; Yeh \& Li, 1998).

The Lunan Stone Forest covers a total area of about $350 \mathrm{~km}^{2}$, but the human impacts are not homogeneous throughout that area, generally being greatest in the areas of highest population density and tourism. Accordingly, the current land use and land cover analysis focuses on a high-resolution (1 meter) Ikonos satellite image covering the core of Lunan, which is a roughly $35 \mathrm{~km}^{2}$ area centered on the highest-priority conservation zone around Shilin Town and the Shilin Park (Fig. 3). The analysis of land use change within 30 years focuses on the Major Stone Forest Park, which covers about $7 \mathrm{~km}^{2}$ and which is the archetypal stone forest area that has been longest exploited, particularly for tourism. This area is demarcated as the highest-level protection area, and it is also the only area within the larger Stone Forest for which the necessary historical land use data is available.

The Ikonos high-resolution (1meter) gray satellite image, for December 23, 2001, was rectified to a map projection (WGS_1984_UTM_Zone_48N). Also employed were the 1:10,000 topographic map, published in 1974, tourist information data, and field survey data. The topographic map was digitized using ArcInfo and transformed into the same coordinate system (Transverse Mercator) as the satellite image. ArcInfo was used because the coverage format supports topologic relations between spatial graphics and because digitizing errors, such as dangling node errors, in which a polygon does not close properly, can be rectified easily. Land use and land cover information was extracted from the satellite image visually, and was ground-checked in July 2002. Information about landscape change was derived by digitizing the 1974 topographic map and comparing this to the 2001 satellite image.

\section{RESULTS}

\section{Current land use and land cover}

Understanding the current land use and land cover status is essential for the government and the public to make informed decisions about future conservation of the Stone Forest landscape. The current land use and land cover map, as identified from the Ikonos image for the entire $35 \mathrm{~km}^{2}$ area, is shown in Fig. 3. Table 1 provides the various land use areas. It shows that exposed pinnacle karst areas - stone forest sensu stricto, cover only $51.8 \%$ of the study area, predominantly in the east and the south. It also shows that $24.8 \%$ of shilin areas are vegetated, whereas $22.4 \%$ are without vegetative cover. Figure 3 also demonstrates that shilin areas are not restricted to any one particular geomorphic setting, and are associated with a variety of soil, vegetation, and hydrologic conditions. It is also evident that construction has now covered nearly six percent of the central stone forest area.

Most valleys, which cover about $19 \%$ of the total area, have been converted to agricultural use. These valleys are important components of the landscape, in that they are natural soil and water storage locations. Their conversion from forest or grassland to farmland has implications for the overall karst ecosystem, not least in terms of diminishing water storage. Less than one percent of the study area is agricultural uplands, on which farming is generally marginal. Forest occupies only $1.2 \%$ of the study area, with mixed forest and farmland covering $5.9 \%$ and water covering $1.4 \%$ of the area. 


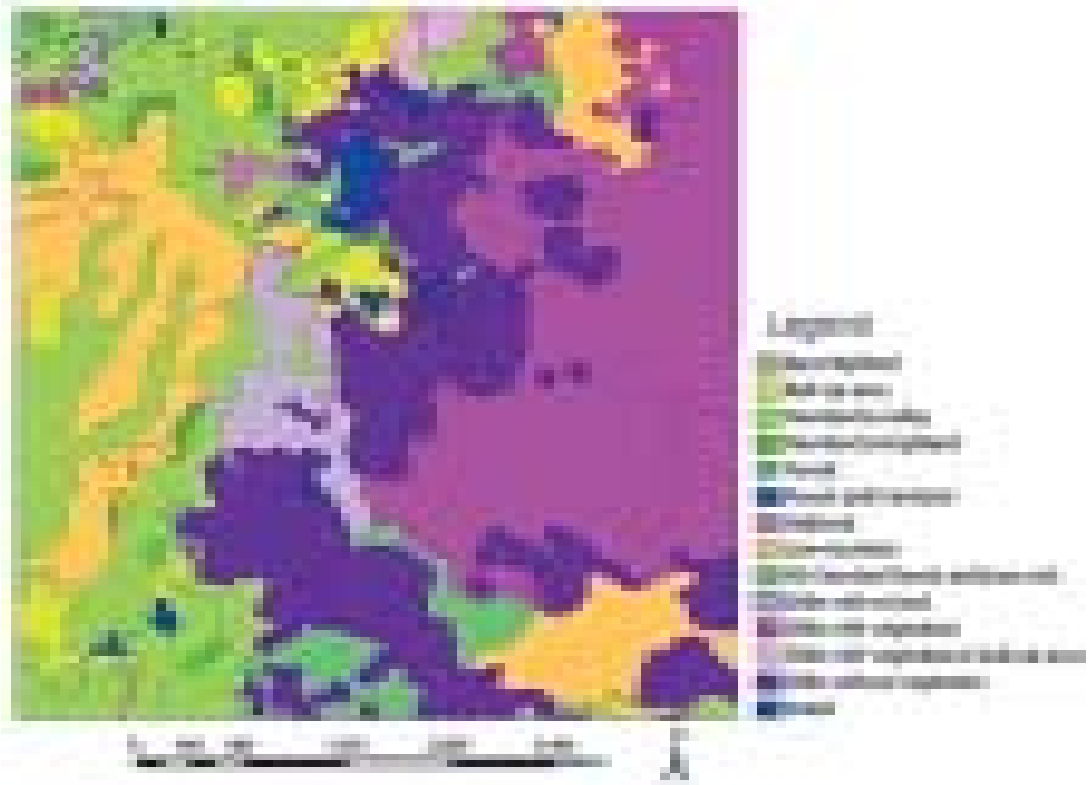

Fig. 3: Land use and land cover map.

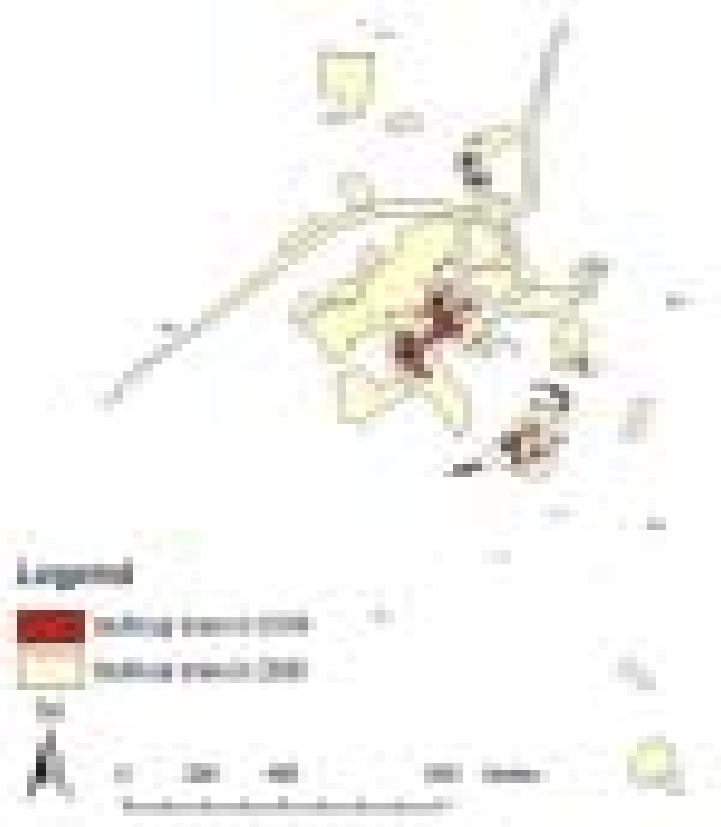

Fig. 4: Built-Up Areas, 1974 and 2001. 

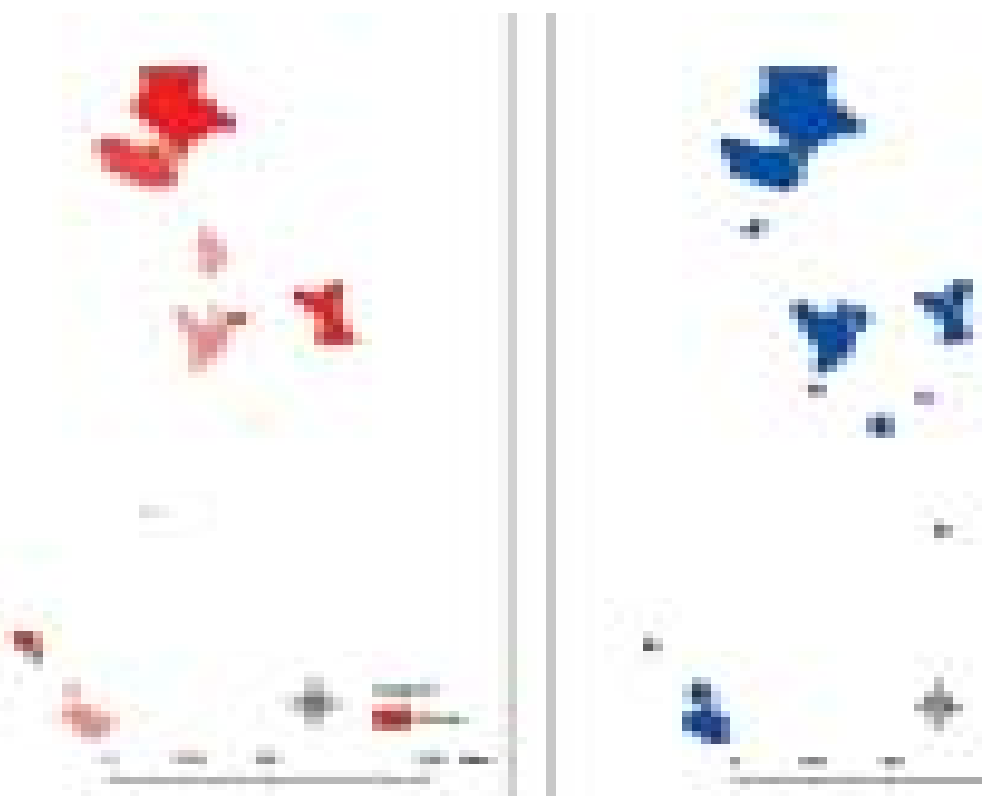

+1

E

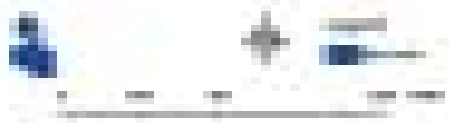

Fig. 5: Surface Water Areas, 1974 and 2001.
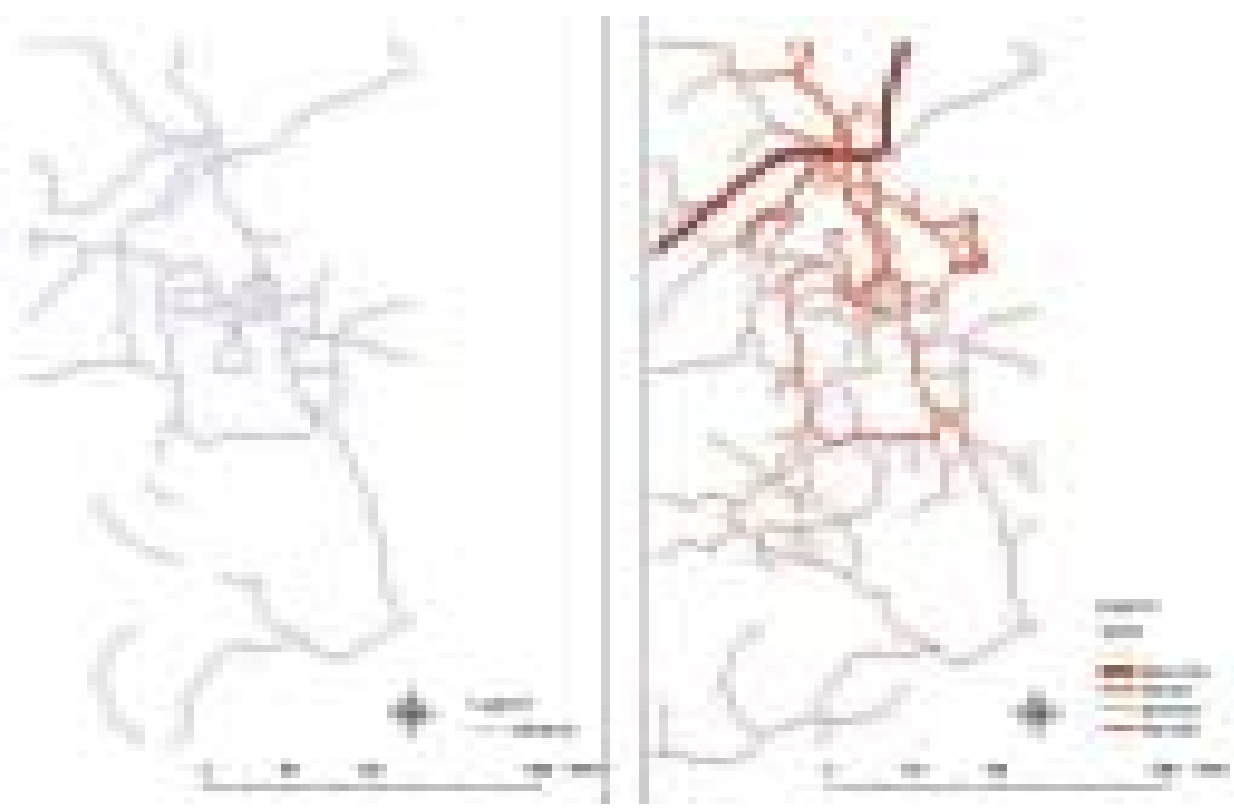

Fig. 6: Road Network, 1974 and 2001. 
Land Use Type

Unknown

Forest and Farmland

Bare Highland

Farmland on Highland

Highland

Vegetated Shilin in Built-Up Area

Forest

Water

Shilin with Red Soil

Mixed Farmland, Forest and Bare rock

Built-Up Area

Low Mountain

Farmland in Valley

Shilin without Vegetation

Shilin with Vegetation
Area (ha)

0.06

3.29

3.51

9.46

14.05

25.92

42.02

47.15

136.37

160.16

189.99

545.49

662.31

778.60

862.43
Percentage

$0.0 \%$

$0.1 \%$

$0.1 \%$

$0.3 \%$

$0.4 \%$

$0.7 \%$

$1.2 \%$

$1.4 \%$

$3.9 \%$

$4.6 \%$

$5.5 \%$

$15.7 \%$

$19 \%$

$22.4 \%$

$24.8 \%$

Table 1: Land Use Areas and Percentages.

\section{LAND USE CHANGE FROM 1974 TO 2001}

Figure 4 and Table 2 provide data on the change in built-up area in the $7 \mathrm{~km}^{2}$ Major Stone Forest park over the past three decades. In 1974 the built-up area was only 0.15 ha but this had increased by 2001 to 38.68 ha - an increase of more than $19,000 \%$.

$\begin{array}{lr}\text { Built-up Area } 1974 \text { (ha) } & 0.15 \\ \text { Built-up Area 2001 (ha) } & 38.68 \\ \text { Increase in Built-up Area (ha ) } & 38.53 \\ \text { Increase in Built-up Area (\%) } & 19250\end{array}$

Table 2: Built-up areas, 1974 and 2001.

Figure 5 shows the distribution of surface water bodies in 1974 and 2001. During that period a 1.6 ha lake shown in the center of the 1974 map has been filled to construct a parking lot, but other small lakes, created by groundwater extraction, have been created as tourist attractions. Table 3 summarizes the 9ha, or $3.36 \%$ decrease in surface water area between 1974 and 2001. While some lakes decreased in area, others were modified by human activities.

$\begin{array}{lr}\text { 1974 Surface Water Area (ha) } & 23.66 \\ \text { 2001 Surface Water Area (ha) } & 22.87 \\ \text { Change in Surface Water Area (ha) } & -0.79 \\ \text { Change in Surface Water Area (\%) } & -3.34\end{array}$

Table 3: Change in Surface Water Area, 1974-2001. 
Figure 6 and Table 4 depict the change in roads between 1974 and 2001 within the Major Stone Forest park, during which time $21.6 \mathrm{~km}$ of road was constructed, an increase of $95.5 \%$. The 2001 road system includes a new expressway to Lunan from the provincial capital, Kunming, together with other new highways and improved roads.

$\begin{array}{ll}1974 \text { Road Length }(\mathrm{km}) & 22.62 \\ \text { 2001 Road Length }(\mathrm{km}) & 44.22 \\ \text { Road Length increase }(\mathrm{km}) & 21.60 \\ \text { Road Length increase }(\%) & 95.48\end{array}$

Table 4: Road Network Change, 1974-2001.

Although the 1974 map does not depict vegetation cover, and hence it is not possible to quantify vegetation change since then, it is apparent that there have also been significant changes in vegetation cover. Vegetation cover has clearly been lost to the expansion of built-up areas and the road network, and also exotic species have been planted to provide ornamental landscaping (Figure 7). These exotic species, although aesthetically attractive, are changing the landscape both visually and ecologically, and may represent threats to populations of native plants and animals.

\section{TOURISM}

Figures 8 and 9 depict visitor numbers from 1980 to 2001, and illustrate the very rapid development during that time. In 1980, 139,000 tourists, including 20,000 non-Chinese, visited the Stone Forest, but by 2000 the numbers had swollen to 1,400,000, including 130,000 nonnationals. By 2001 the total visitor number increased to 1,500,000 - a ten-fold increase from 1980. International tourist numbers increased more than six-fold over the same time period.

Tourism is of great significance to the local economy, and Figure 10 shows the direct and total tourism incomes from 1993 to 2000. The direct tourism income was 9,080,000 Chinese Yuan (A) in 1993, increasing sevenfold to 70,000,000 Az in 2000. During the same seven-year period, total tourism income increased more than eightfold.

\section{ANALYSIS AND DISCUSSION}

The results clearly demonstrate the current land use situation and the extent of land use change since 1974 , to which tourism is clearly a major contributor.

Exposed pinnacle karst - stone forest sensu stricto - covers less than $52 \%$ of the $35 \mathrm{~km}^{2}$ study area, which suggests that it may be possible to identify locations within the broader stone forest that are particularly worthy of conservation, and that a wider variety of conservation techniques may be appropriate, although the overall ecosystem warrants consideration. Approximately half of the pinnacle area has some vegetation cover, the other half being denuded. The overall limited vegetative cover warrants concern, particularly the lack of forest cover. Trees and grassland can to some extent subdue the visual impact of the pinnacles, but this would be more than offset by the potential reduction of soil erosion, the increase in biodiversity and the improvement in air quality, the latter reducing potential corrosion of the pinnacles themselves. A comprehensive re- 


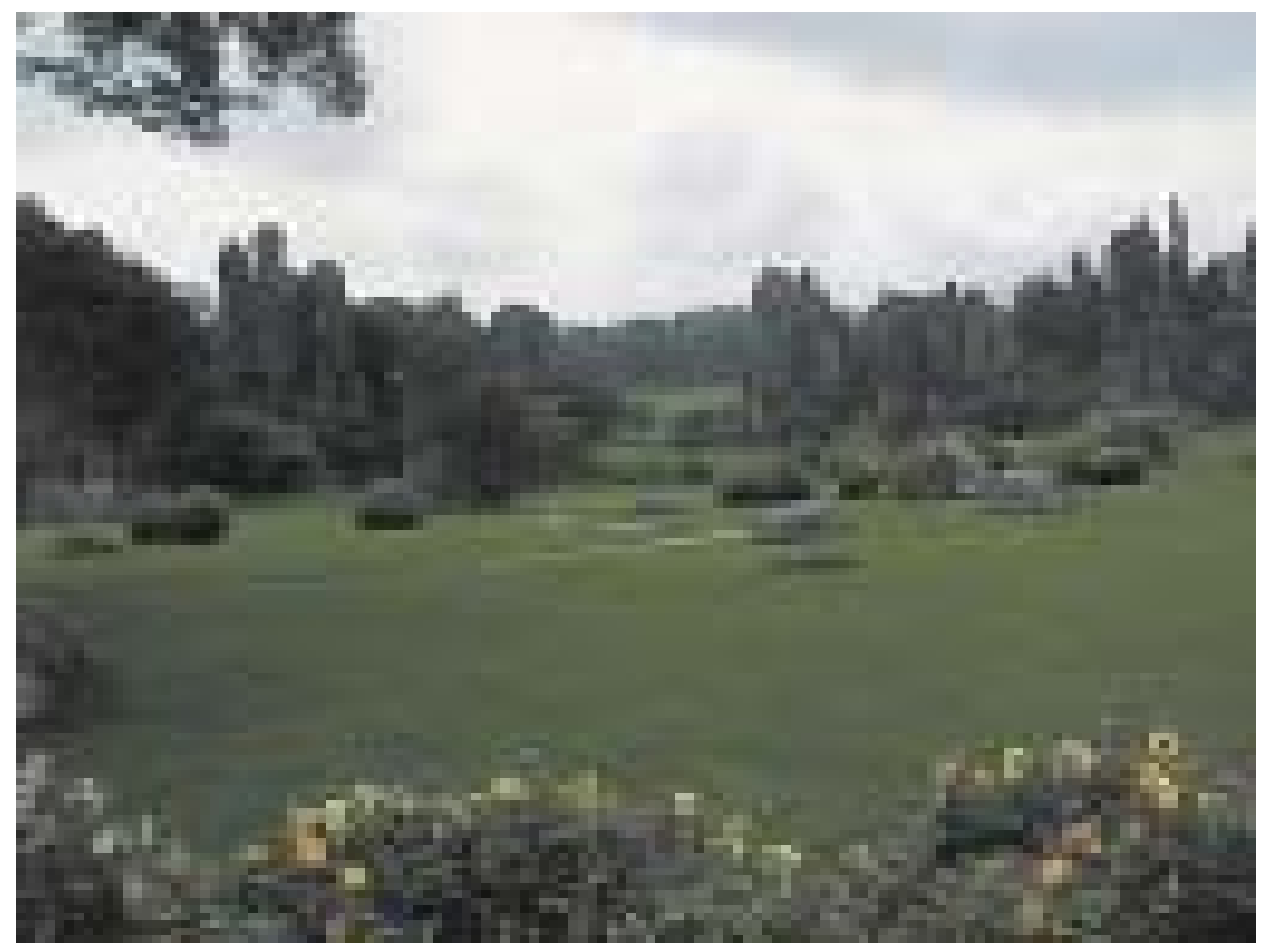

Fig. 7: Exotic vegetation cover.

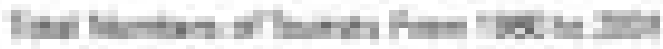

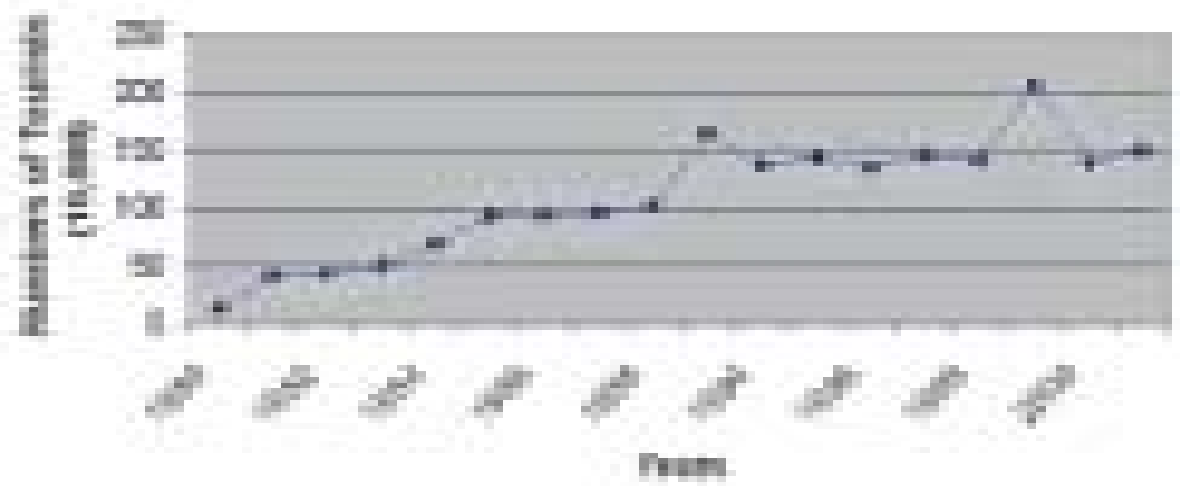

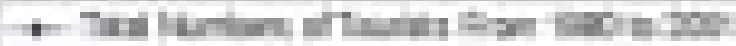

Fig. 8: Visitor Numbers from 1980 to 2001. 


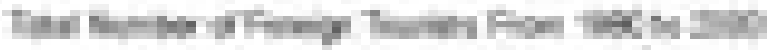

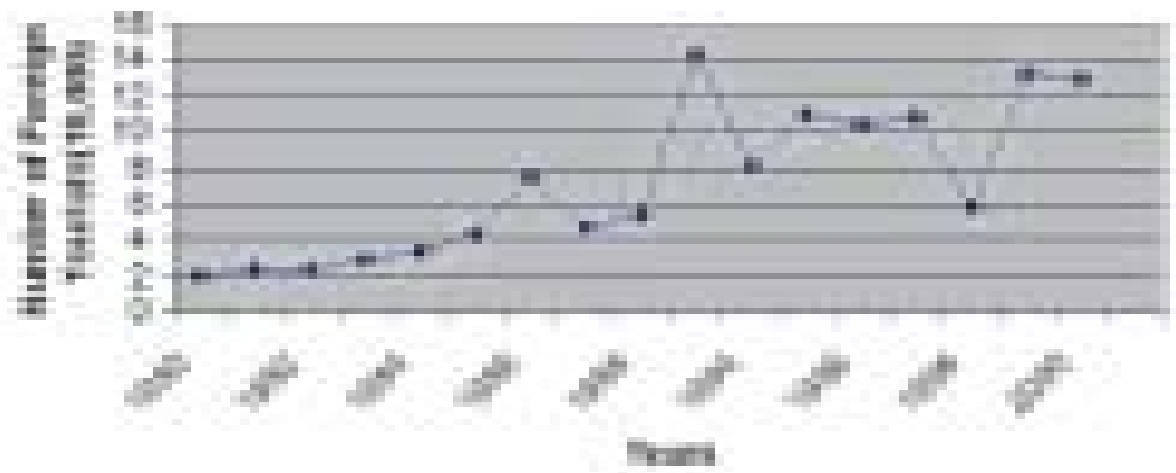

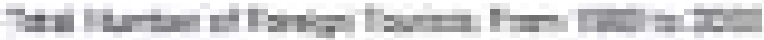

Fig. 9: International Visitor Numbers from 1980 to 2001.

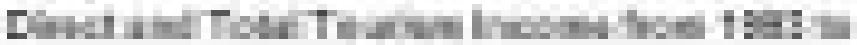
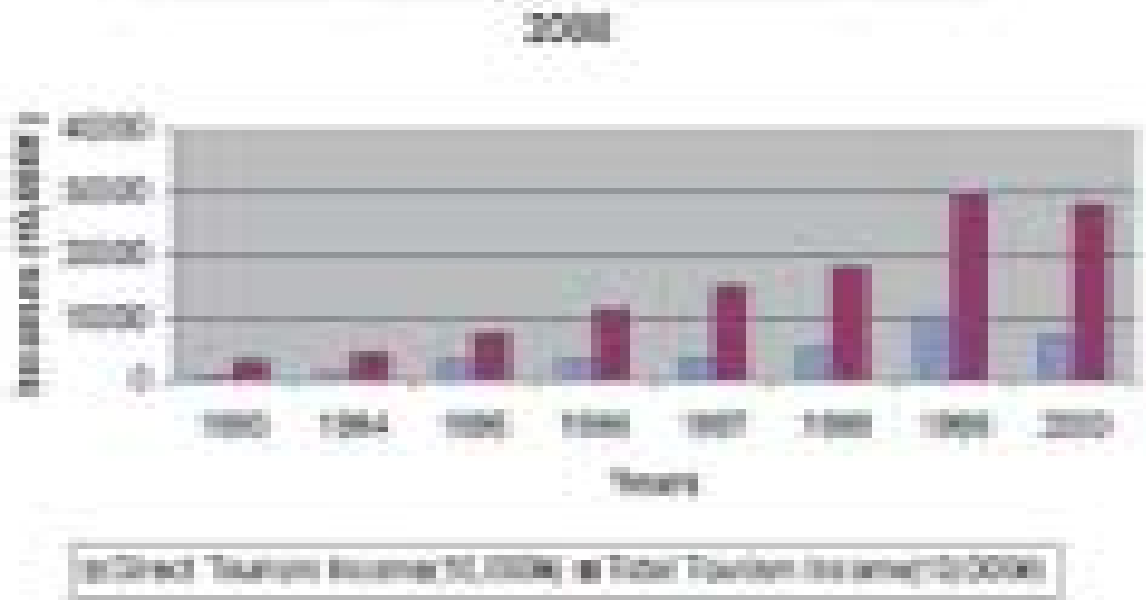

Fig.10: Direct and total tourism income from 1993 to $2000(1 \$=8.27$ A). 
vegetation policy seems warranted, perhaps focusing on the maintenance of existing farmland and the establishment of mixed vegetation on highland and denuded areas.

Hydrologic changes, particularly the increasing abstraction of groundwater for tourism, agricultural and industrial purposes, also mandate concern, with conservation efforts increasingly being necessary.

Construction has now covered nearly six percent of the broader stone forest area, focusing attention on whether future construction should be limited as an overall conservation technique. Although some recent construction is associated with residential and industrial development, much of it is a function of the burgeoning tourism industry, and the associated hotels, roads and parking areas. Traffic congestion and vehicular pollution are serious associated problems, as are the visual and other blight produced by construction industries in general.

The positive impact of tourism and associated development on the local and regional economy cannot be dismissed, but the increasing conflict between economic development and landscape conservation must be dealt with very carefully. This not only involves in the problem of shortterm versus long-term benefit, but also concerns the conservation of natural and cultural heritage. The Stone Forest landscape is at risk because of excessive exploitation, and its conservation is paramount.

\section{CONCLUSION}

The Stone Forest landscape in Lunan is of great significance both from a scientific and cultural perspective and to the local economy, but its inherent ecological fragility and the scale of human impact have resulted in considerable land cover change over the last three decades, and the implementation of effective conservation measures is of paramount urgency. GIS and remote sensing are important tools for relevant data collection and manipulation, although the acquisition and input of data is time-consuming and costly, and they have much to contribute to the development of effective conservation strategies. This research focused only on the central Stone Forest area, but highlights the essence of the ongoing landscape change. Decision-makers need more GIS data to assess landscape change across the whole region and to develop appropriate conservation and development policy.

Landscape change in the Stone Forest is driven largely by tourism-related development, which threatens to undermine the raison d'etre for the national park itself. Reconciliation of landscape conservation and local economic development will not be easy, but a holistic, ecosystem-based approach is necessary if both sets of interests are not to flounder.

\section{ACKNOWLEDGMENTS}

Financial support for C. Zhang was provided by a Mary Jo Read Scholarship from the Department of Geography at the University of Wisconsin-Milwaukee. Thanks to Professor Tao Tang of the Department of Geography \& Planning, Buffalo State University of New York, for providing the topographic map and the Iknonos images, and to Professor Song Linhua of the Institute of Geography, Chinese Academy of Sciences, for providing the tourism data. 


\section{REFERENCES}

Day, M.J., 1997: Conservation Issues in Stone Forest Karst. - Stone Forest: A Treasure of Natural Heritage, ed. Song, L, Waltham, T., Cao, N. \& Wang, F., China Environmental Science Press, 17-22.

Department of the Environment (DoE), 1987: Handling Geographic Information, - HMSO, London Gao, J. \& Skillcorn D., 1995: A GIS-remote sensing approach to detection of land cover change in Auckland urban-rural fringe, - Proceedings of Geoinformatics '95 Hong Kong 1, 222-229.

Geng, H. \& Cheng, S. \& Luo, S., 1987: Geological Excursion Guidebook to the Karst Landscape in the Lunan Region, Yunnan Province, - Bureau of Geology and Mineral Resources, Yunnan Province.

Huang, C. \& Liu, H., 1998: Karst of Yunnan, - South China Karst I, 11-17, Ljubljana.

Huntoon, P. W., 1992: Hydrogeologic characteristics and deforestation of the Stone Forest karst aquifers of South China, - Ground Water, 30, 167-176.

Huntoon, P. W., 1993. The hydrogeological impacts of deforestation on the sensitive stone forest karst aquifers in south China, - Karst Landscape and Cave Tourism, ed. Song, L. \& Ting, H., China Environmental Science Press, 112-118.

Kranjc, A. \& Liu, H., 2001: Lunan "Shilin" (Stone Forest) human impact and protection of (eventual) World Heritage site (Yunnan, China), - Acta Carsologica 30 (1), 25-38.

Lin, J., 1997: Genesis of Lunan Stone Forest and Its Geomorphological Significance. - Stone Forest: A Treasure of Natural Heritage, ed. Song, L, Waltham, T., Cao, N. \& Wang, F., China Environmental Science Press, 30-33.

Miguel-Anyanz. J.S. \& Biging, G.S., 1997: Comparison of single-stage and multi-stage classification approaches for cover type mapping with TM and SPOT data, - Remote Sensing of Environment 59, 92-104.

Song, L., 1986: Origination of stone forests in China, - International Journal of Speleology, 15, 313.

Song, L.,Waltham, T., Cao, N. \& Wang, F. 1997. Stone Forest A Treasure of Natural Heritage. China Environmental Science Press, 136pp.

Waltham, A.C., 1984: Some Features of Karst Geomorphology in South China, - Transactions British Cave Research Association, 11,185-198.

Yeh, A.G. \& Li, X., 1998: Sustainable land development model for rapid growth area using GIS, - International Journal of Geographical Information Science 12,169-189.

Yuan, D., 1988: Glossary of Karstology, - Geological Publishing House, Beijing.

Yuan, D.\& Zhu, D. \& Weng, J. \& Zhu, X. \& Han, X. \& Wang, X. \& Cai, G. \& Zhu, Y. \& Cui, G. \& Deng, Z., 1991: Karst of China, - Geological Publishing House, Beijing.

Zhang, F. \& Geng H. \& Li, Y., 1997: Study on The Lunan Stone Forest Karst, China, - Yunan Science and Technology Press.

Zhang, S., 1984: The Development and Evolution of Lunan Stone Forest, - Carsologica Sinica 3(2), 78-87. 